\title{
Evaluation of the MC 3125 Parachute SHROUd CutTer
}

C. A. Campos

DEVELOPMENT DIVISION

MARCH 1977

\author{
For \\ Sandia Laboratories \\ Albuquerque, New Mexico \\ P.O. No. 03-2685 \\ $\&$
}

Process Development

Endeavor No. 202

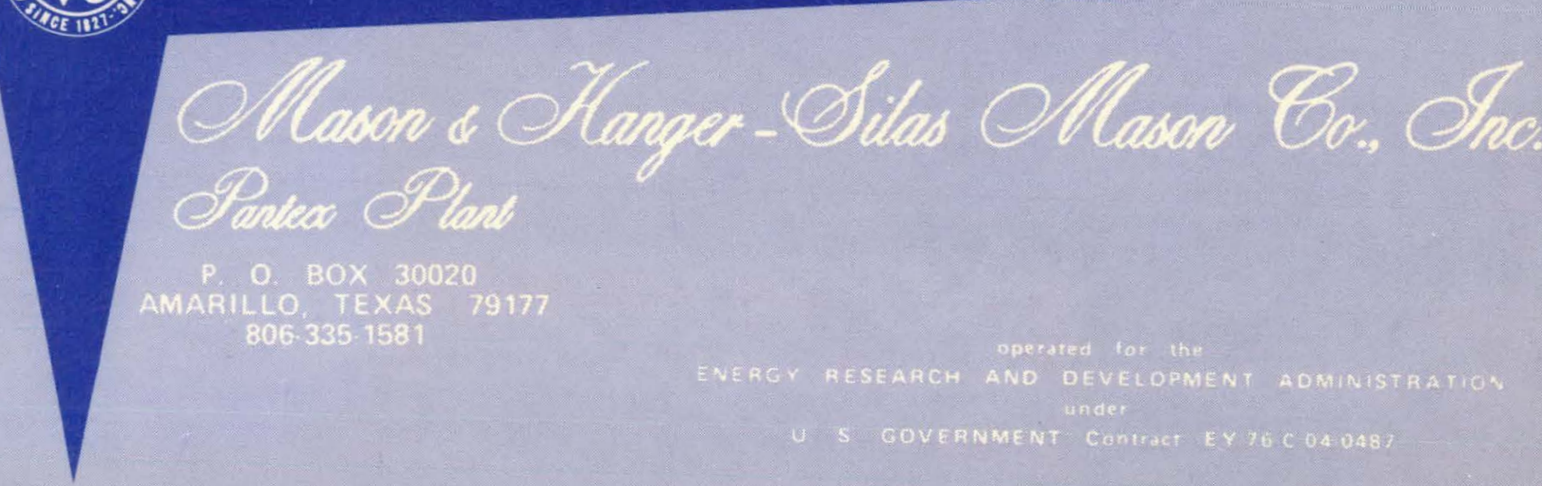




\section{DISCLAIMER}

This report was prepared as an account of work sponsored by an agency of the United States Government. Neither the United States Government nor any agency Thereof, nor any of their employees, makes any warranty, express or implied, or assumes any legal liability or responsibility for the accuracy, completeness, or usefulness of any information, apparatus, product, or process disclosed, or represents that its use would not infringe privately owned rights. Reference herein to any specific commercial product, process, or service by trade name, trademark, manufacturer, or otherwise does not necessarily constitute or imply its endorsement, recommendation, or favoring by the United States Government or any agency thereof. The views and opinions of authors expressed herein do not necessarily state or reflect those of the United States Government or any agency thereof. 


\section{DISCLAIMER}

Portions of this document may be illegible in electronic image products. Images are produced from the best available original document. 


\section{NOTICE}

This report was prepared as an account of work sponsored by the United States Government. Neither the United States nor the United States Energy Research and Development Administration, nor their employees, nor any of their contractors, subcontractors, or their employees, makes any warranty, express or implied, or assumes any legal liability or responsibility for the accuracy, completeness or usefulness of any information, apparatus, product or process disclosed, or represents that its use would not infringe privately-owned rights.

Printed in the United States of America

Available from

National Technical Information Service

U. S. Department of Commerce

5285 Port Royal Road

Springfield, VA 22161

Price: Printed Copy $\$ 3.50$; Microfiche $\$ 2.25$ 


\section{EVALUATION OF THE MC 3IZS PARACHUTE SHROUD CUTTER}

\author{
C. A. Campos
}

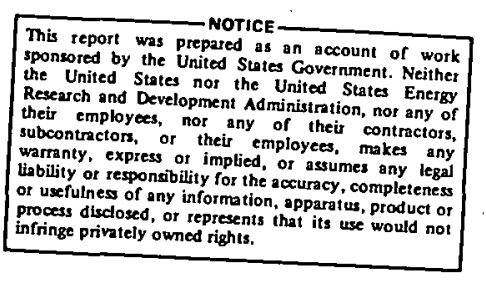

ABSTRACT

This is the second of two reports (C. A. Campos, MC 3125 ALSC Cutting Ability Development, MHSMP-76-29, April-June 1976) which describes the test fire program to evaluate the ability of the Sandia-furnished HNS/ALSC to sever Kevlar parachute shroud lines. The test program consisted of firing MC 3125 simulators, including some with MC 3132 detonators. Imposed environments included high humidity, high and low temperatures, and thermal shock cycles. Additional tests were done to investigate the effects of bending the HNS/ALSC and 18 wedge ban tests were done to establish a method of qualifying HNS/ALSC. materialis.

Included herein are areas of work which support the Sandiafunded work but are performed using Process Development funds. These areas in general cover the development of test techniques to support Sandia-funded work. Major items are a lot qualification test technique being developed and the investigation into the effects of bending the AlisC.

\section{INTRODUCTION}

HNS aluminum-1inear-shaped-charge (ALSC) was tested for ultimate use as a cutter of $53.4 \mathrm{kN}$ tensile Kevlar parachute shroud lines and two $2.4 \mathrm{~mm}$ packing shroud lines. Of particular interest was the effect humidity may have on the cutting ability of ALSC. Special emphasis was placed on providing a $98 \%$ relative humidity environment at $52 \mathrm{C}$, and it was found that moisture appears to have a deleterious effect on cutting ability.

The tests have shown that the ALSC adequately cuts the Kevlar shroud lines but that special precautions must be taken to prevent extreme moisture saturation of the shroud lines imulediately prior to use.

\section{RELATIVE HUMIDITY TESTS}

Three tests were devised to further evaluate the performance of ALSC on cutting Kevlar in a high humidity environment. The primary difference from former tests was the operating procedures followed in handling of the test units during and after humidity exposure. In these tests, a plastic bag used to seal moisture around the unit after removal from the humidity chamber was left open during the soak period as before; however, the test units were elevated off the bottom of the bag and extra. care taken to avoid contact with the sides.

There were two configurations tested. In one case a full ring MC 3125 simulator and EX-12 detonator were 
assembled with twelve $53.4 \mathrm{kN}$ tensile FRL No. 5034-146-5 shroud lines. Detonation velocity was not measured on this test. Fig. 1 illustrates the second type of test unit configuration wherein a full ring was sawcut into 120 degree segments. Aside from the different number of shroud lines tested (three each segment), the full ring simulator and segmented units were identical.

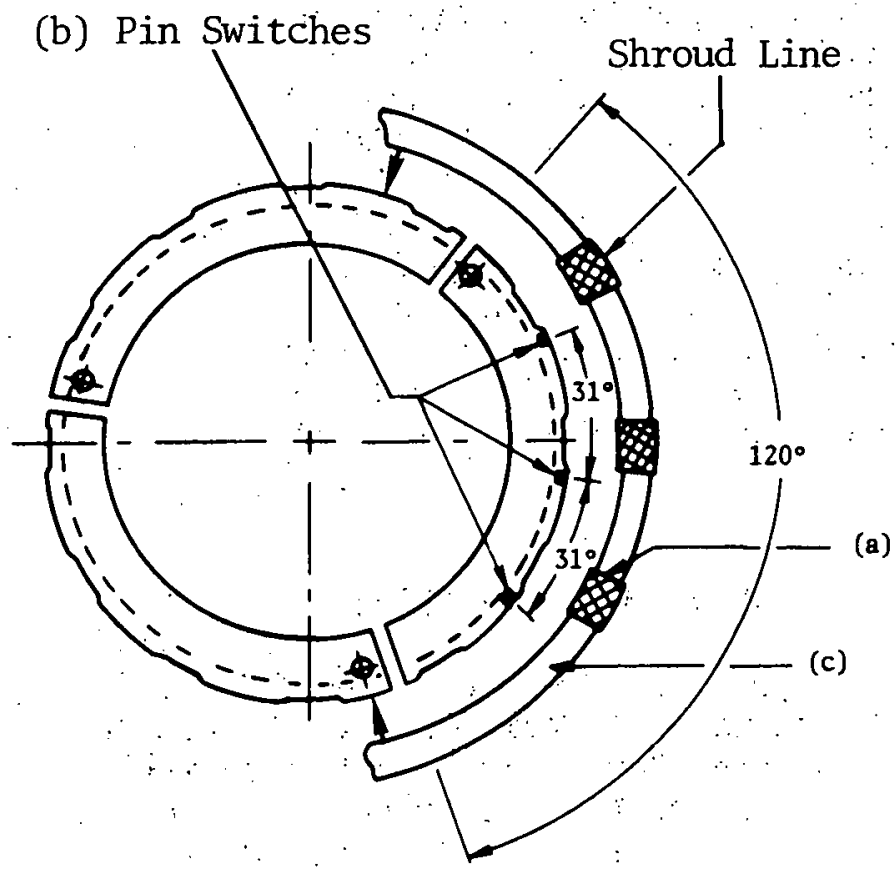

(a) $2.54 \mathrm{~mm}$ ALSC standoff to shroud lines.

(b) T-iming switches used on segmented units only.

(c) Anvil - Backing for shroud line cutting and witness plate. Ilolding steel fixtures not shown.

Fig. 1.. Humidity Test Assembly

\section{SHOTS I AND 2 - FULL RING SIMULATORS}

Det. Vel. Not Measured

Humidity $\quad 98 \% \mathrm{RH}, 20$ hours at $52 \mathrm{C}$

Final Temp. Shot $1-4$ hours at $85 \mathrm{C}$ Shot 2 - 4 hours at $-54 \mathrm{C}$

Cutting $100 \%$

A11 shroud lines were successfully cut in these tests. Also, the new procedural steps in testing the units appeared to indicate that prior failures were due to over-test in humidity, i.e., water was allowed to accumulate on the shroud lines.

SHOT 3 - SEGMENTED

Det. Vel. (1) $7.11 \mathrm{~km} / \mathrm{sec}$

(2) $7.12 \mathrm{~km} / \mathrm{sec}$

(3) $.7 .09 \mathrm{~km} / \mathrm{sec}$

Humidity - $98 \% \mathrm{RH}, 20$ hours at $52 \mathrm{C}$

Final Temp. 4 hours at $85 \mathrm{C}$ Cutting $\quad 100 \%$

A11 three units were assembled on the same holding fixture with three shroud lines each. Three timing switches recorded detonation velocity. During the 4-hour environmental conditioning at $85 \mathrm{C}$ the shroud lines possibly experienced some drying. This was purposely specified.

\section{SHOT 4 - SEGMENTED}

Det. Vel.

(1) $7.09 \mathrm{~km} / \mathrm{sec}$

(2) $7.09 \mathrm{~km} / \mathrm{sec}$

(3) $7.10 \mathrm{~km} / \mathrm{sec}$

Humidity : None

Temperature 4 hours at $-54 \mathrm{C}$

Cutting $100 \%$ 
All three units were again mounted on the same holding fixture, so that the same temperature would be experienced. Humidity was purposely omitted from the environmental exposure for this test.

\section{DETONATION VELOCITY EFFECTS DUE TQ BENDING ALSC}

These tests were designed to evaluate the effects of bending $5.3 \mathrm{~g} / \mathrm{m}$ ALSC on detonation velocity. Fig. 2 shows

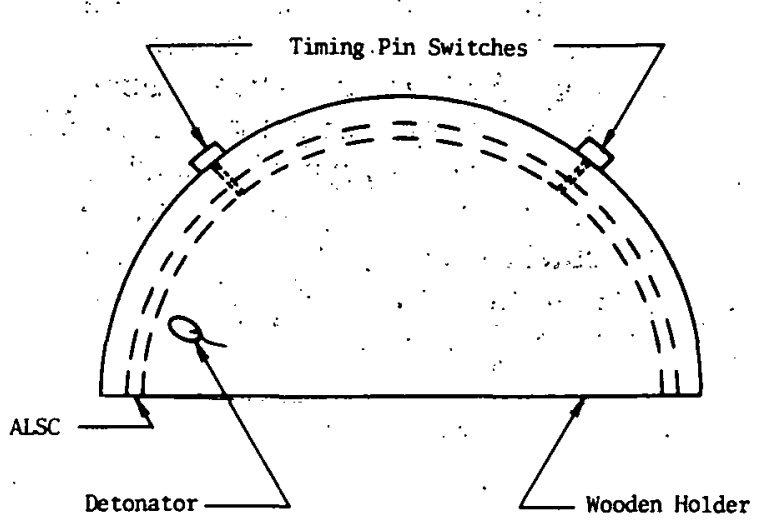

ALSC Side-Detonation

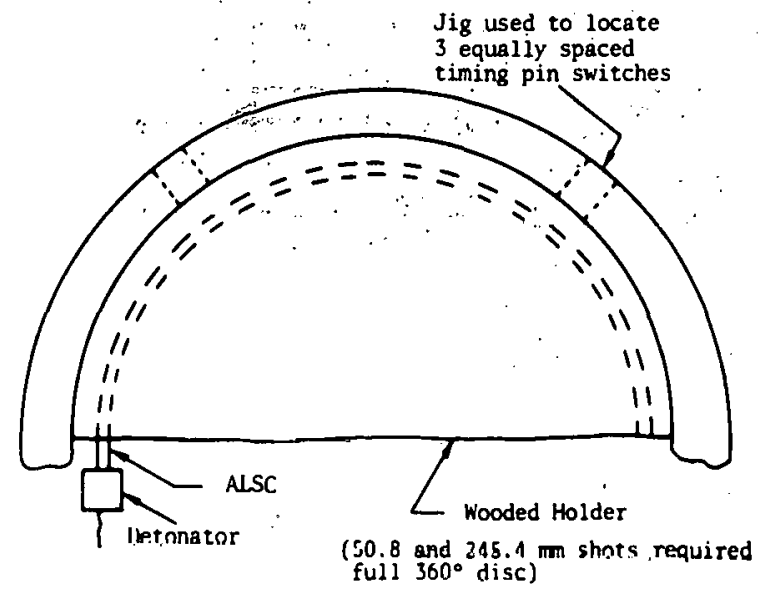

ALSC End-Detonation

Fig. 2. ALSC in Bent Configuration the two approaches used to accomplish this. The difference in the two approaches is the distance measurement between the timing switches. A technique introduced in the first report consisted of employing plastic shim stock foil on the : side-detonation shots. These foil strips are placed along the ALSC groove and holes punched at the pin locations. Gaps between holes were then measured. In the other shots, a jig was fabricated: for each different radius to place the pins consistently into position.

Table I gives the detonation velocities measured. The first four shots using a $76.2 \mathrm{~mm}$ radius are inconsistent with the shots using the jig measuring technique. In any event, there does not seem to be a substantial change in velocity until the radius reaches $25.4 \mathrm{~mm}$ : This change should not affect cutting ability since the MC 3125 radius is $152.4 \mathrm{~mm}$.

Table I. Detonation Velocity Effocts Do to Bending ALSC

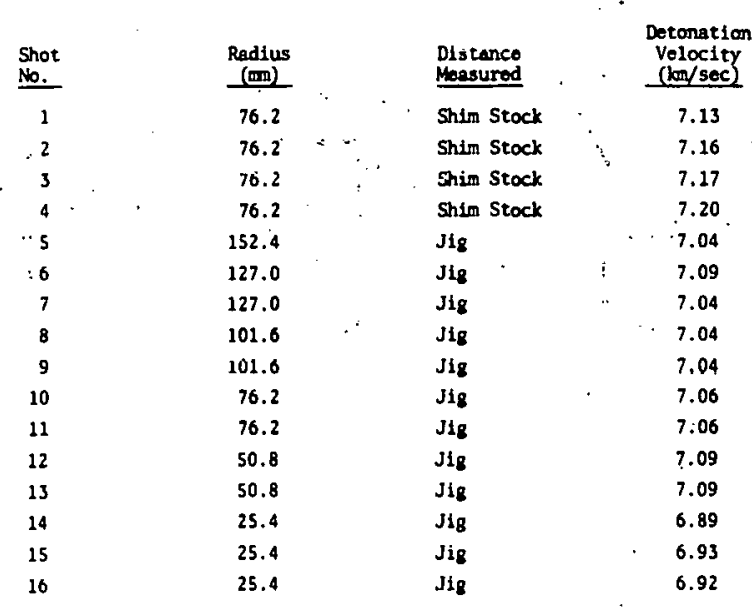

NOTE: Shots fired at ambient temperature ALSC core loaded at $5.3 \mathrm{~g} / \mathrm{m}$. 


\section{LOT QUALIFICATION}

There were two basic reasons for performing these series of tests: The first was to establish a method for qualifying lot shipments of HNS/ALSC. Secondly, by use of this technique, its effectiveness was to be demonstrated on the lot shipment on hand. The setup is illustrated in Figs. 3 and 4 :

Aluminum spacers were machined to provide a standoff of $2.54 \mathrm{~mm}$ for cutting the shroud lines, leaving a standoff of $4.70 \mathrm{~mm}$ between the ALSC and the aluminum witness plate. Six each tests were done at $-54 \mathrm{C}$, ambient, and $82 \mathrm{C}$.

Kevlar shroud lines were positioned as shown to obtain go, no-go cutting information. The test results showed a successful cut of all lines including one $26.6 \mathrm{kN}$ Kevlar shroud line included at each temperature.
Detonation velocity for each test was measured. Only a sma11, increase in detonation velocity at $-54 \mathrm{C}$ was noted but was not considered significant.

\section{RUPTURE ABILITY}

The design of the witness plate served two purposes. Zone 1 in Fig. 3 represents the region used to measure rupturing ability of the ALSC. This measurement is given as rupture thickness. Table II gives the results for velocity and rupture. Sub-1ot, as shown, designates the particular shipment available for testing at the time. Sub-lot numbers are used to explain the feasibility of this technique as a method for qualifying HNS/ALSC. The results show some inconsistencies in rupture thickness. To obtain more consistent results it appears the ALSC must maintain alignment over the witness plate by providing adequate backing for the ALSC.

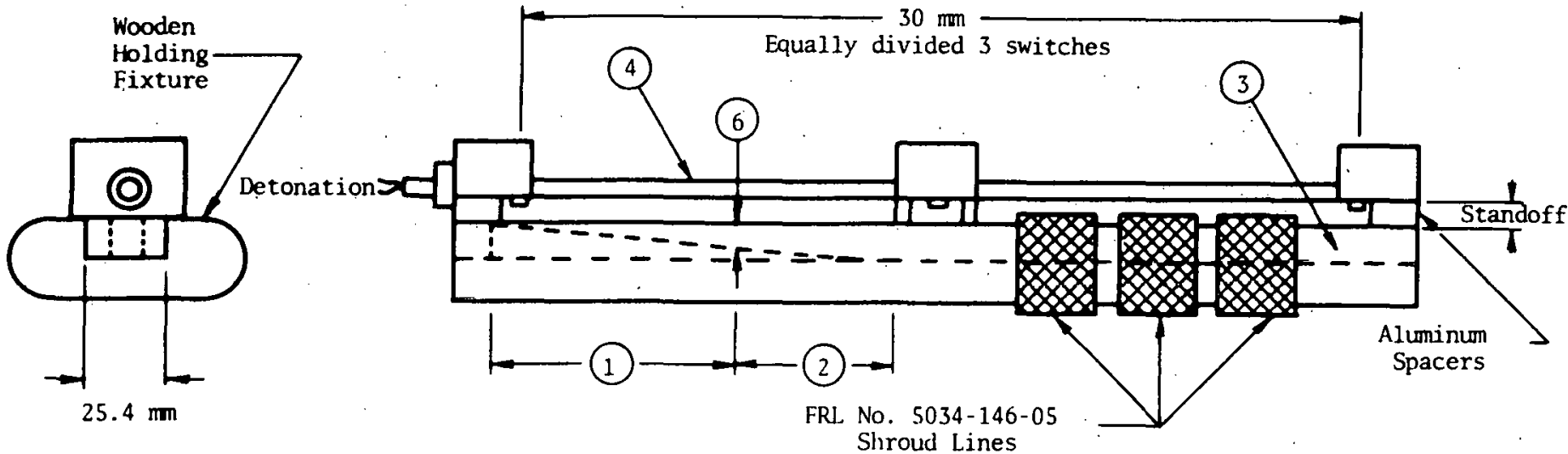

1 Zone for measuring depth of penetration.

2 Zone for measuring depth of cut.

3 Wedged witness plate - 6061 T6 aluminum.

4 Aluminum shape charge (ALSC).

5 Timing switches $-0.991 \mathrm{~mm}$ diameter coated with $0.127 \mathrm{~mm}$ Parylene (distance set with gaged $\mathrm{jig}$ ).

6 Rupture thickness.

Fig. 3. Proposed ALSC Lot Qualification Technique 


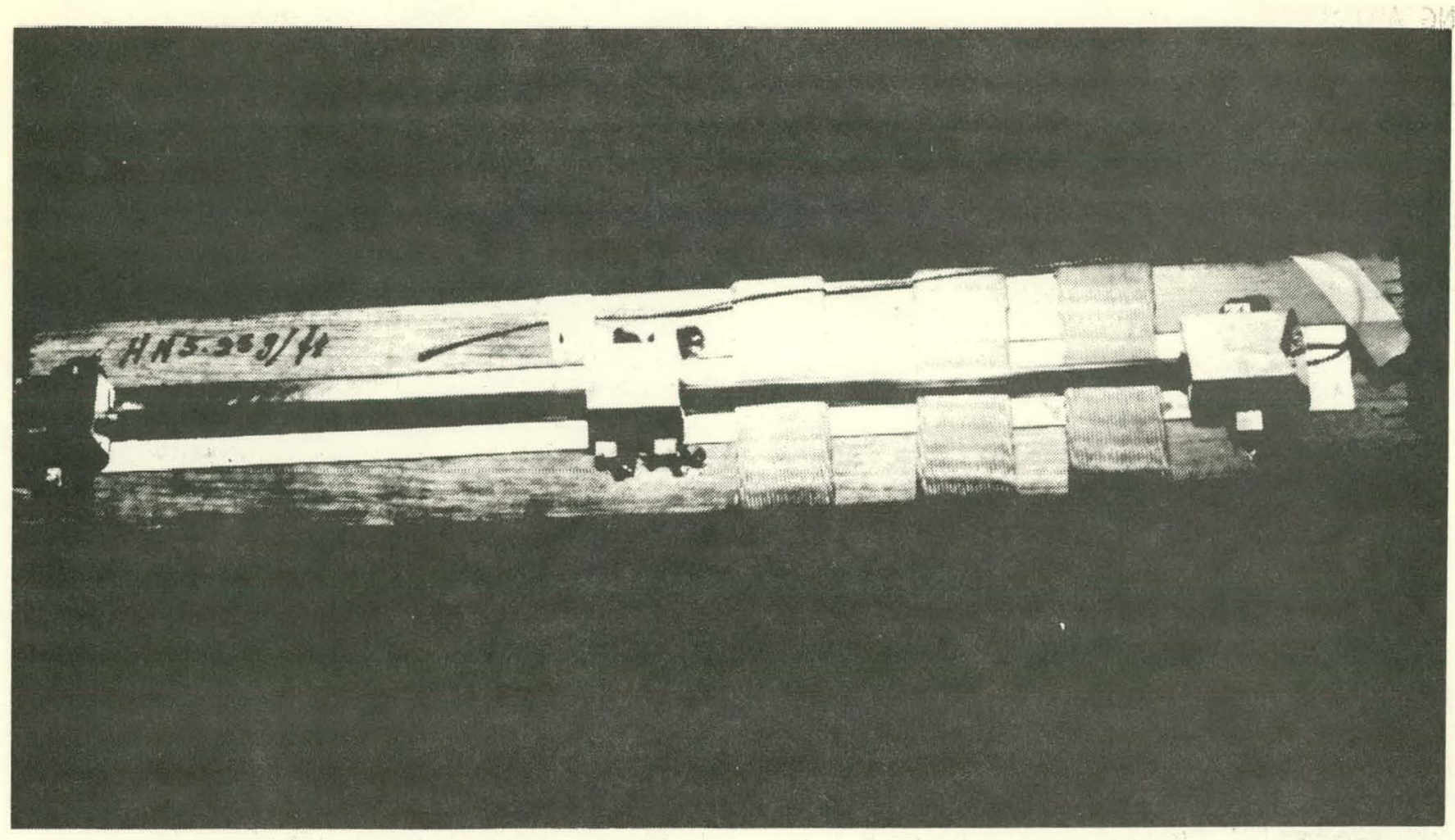

Fig. 4. Proposed ALSC Lot Qualification Assembly

Table II. Qualification Tests and Rupture Results

\begin{tabular}{|c|c|c|c|c|c|c|c|}
\hline $\begin{array}{l}\text { Shot } \\
\text { No. }\end{array}$ & $\begin{array}{l}\text { Sub-Lot } \\
\text { No. } \\
\end{array}$ & $\begin{array}{l}\text { Core } \\
\text { Load } \\
(\mathrm{g} / \mathrm{m}) \\
\end{array}$ & $\begin{array}{l}\text { Temperature } \\
\text { (C) }\end{array}$ & $\begin{array}{c}53.4 \mathrm{KN} \\
\text { Line Cut } \\
\left(\frac{\mathrm{o}}{0}\right) \\
\end{array}$ & $\begin{array}{l}71.2 \mathrm{KN} \\
\text { Line Cut } \\
\left(\frac{\%}{\%}\right) \\
\end{array}$ & $\begin{array}{l}\text { Velocity } \\
\text { (km/sec) } \\
\end{array}$ & $\begin{array}{l}\text { Thickness } \\
\text { of Rupture } \\
\text { (mm) }\end{array}$ \\
\hline 1 & None & 5.31 & Ambient & $3(100)$ & - & 7.05 & 5.23 \\
\hline 2 & 5766 & 6.22 & Ambient & $2(100)$ & $1(100)$ & 6.99 & $\begin{array}{l}3.23 \\
4.52\end{array}$ \\
\hline 3 & 5776 & 5.97 & Ambient & $3(100)$ & - & 6.98 & 5.23 \\
\hline 4 & 5777 & 6.20 & Ambient & $3(100)$ & - & 6.96 & 4.42 \\
\hline 5 & 5778 & 5.06 & Ambient & $3(100)$ & - & 6.97 & 4.83 \\
\hline 6 & 5779 & 6.02 & Ambient & 3 (100) & - & 6.98 & 5.21 \\
\hline 7 & None & 5.31 & -54 & $3(100)$ & - & 7.09 & 4.32 \\
\hline 8 & 5766 & 6.22 & -54 & $3(100)$ & - & 7.10 & 4.78 \\
\hline 9 & 5776 & 5.97 & -54 & $2(100)$ & $1(100)$ & 7.01 & 4.57 \\
\hline 10 & 5777 & 6.20 & -54 & 3 (100) & - & 7.00 & 4.72 \\
\hline 11 & 5778 & 5.96 & -54 & $3(100)$ & - & 7.09 & 4.52 \\
\hline 12 & 5779 & 6.02 & -54 & $3(100)$ & . & 7.01 & 4.32 \\
\hline 13 & None & 5.31 & 82 & 2 (100) & $1(100)$ & 6.99 & 5.36 \\
\hline 14 & 5766 & 6.22 & 82 & $3(100)$ & - & 6.97 & 5.48 \\
\hline 15 & 5770 & 5.97 & 82 & 3 (100) & - & 6.95 & 5.26 \\
\hline 16 & 5777 & 6.20 & 82 & $3(100)$ & - & 6.95 & 5.18 \\
\hline 17 & 5778 & 5.96 & 82 & $3(100)$ & - & 7.01 & 5.18 \\
\hline 18 & 5779 & 0.02 & 82 & $3(100)$ & - & 7.01 & 5.18 \\
\hline
\end{tabular}


CUTTING ABILITY

Zone 2 in Fig. 3 represents the region used to measure cutting depth of ALSC into a witness plate. Cutting depth here is defined as the depth which ALSC can cut into an adequately supported target. In this particular application an aluminum plate was used. A dial indicator was utilized to take a total of nine readings per specimen at approximately every $6 \mathrm{~mm}$ along a $50 \mathrm{~mm}$ sample. These measurements show an irregular pattern left on the witness plate. Figs. 5, 6 and 7 show the pattern of each witness plate.

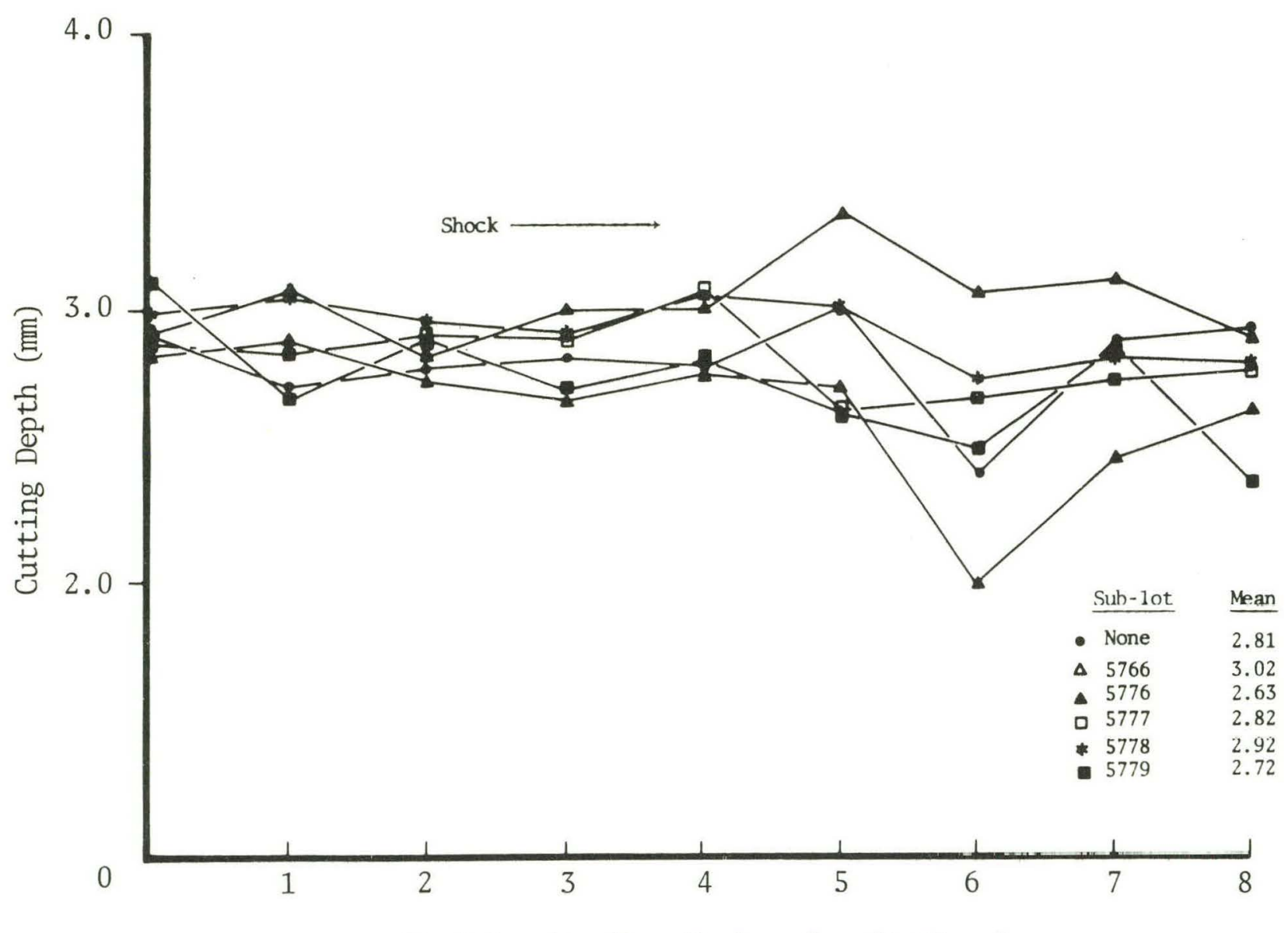

Position Reading Number (one/6.35 mm)

Fig. 5. ALSC Cutting Profile into Aluminum (-53.9 C, ALSC Standoff $4.70 \mathrm{~mm})$ 


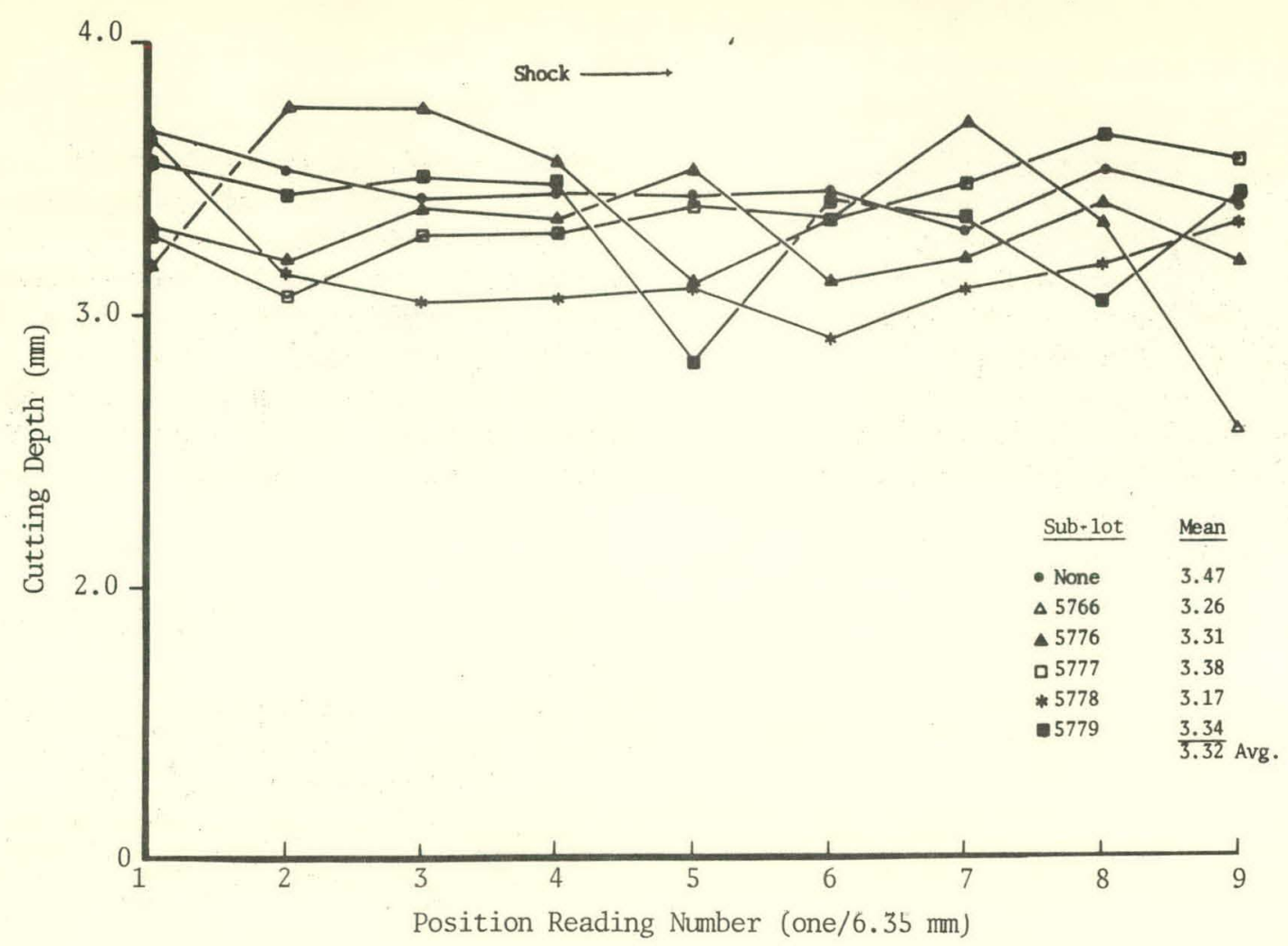

Fig. 6. ALSC Cutting Profile into Aluminum (Ambient Temprature, ALSC Standoff $4.70 \mathrm{~mm}$ )

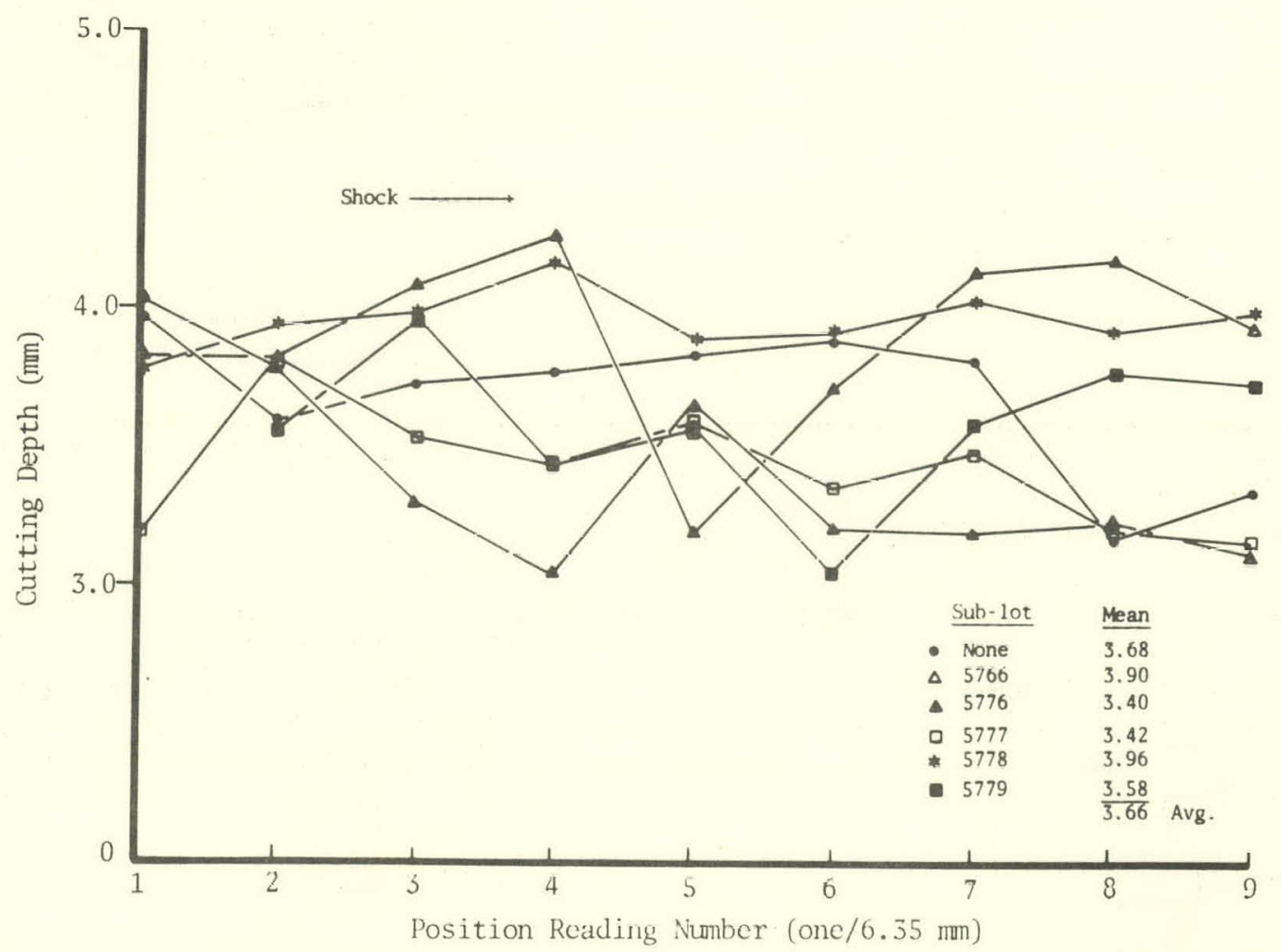

Fig. 7. ALSC Cutting Profile into Aluminum (82 C, ALSC Standoff 4.70 띠) 
The plot in Fig. 8 shows the effect of temperature on the cutting depth. These data should be used only to anticipate the increased cutting depth into aluminum as a function of temperature since ALSC confinement and standoff affect the cutting. Furthermore, the temperature effects may be attributed either to the witness plate or the ALSC itself or both. No attempt has been made to differentiate between them.

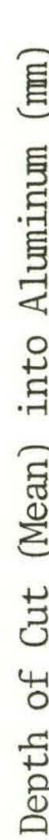

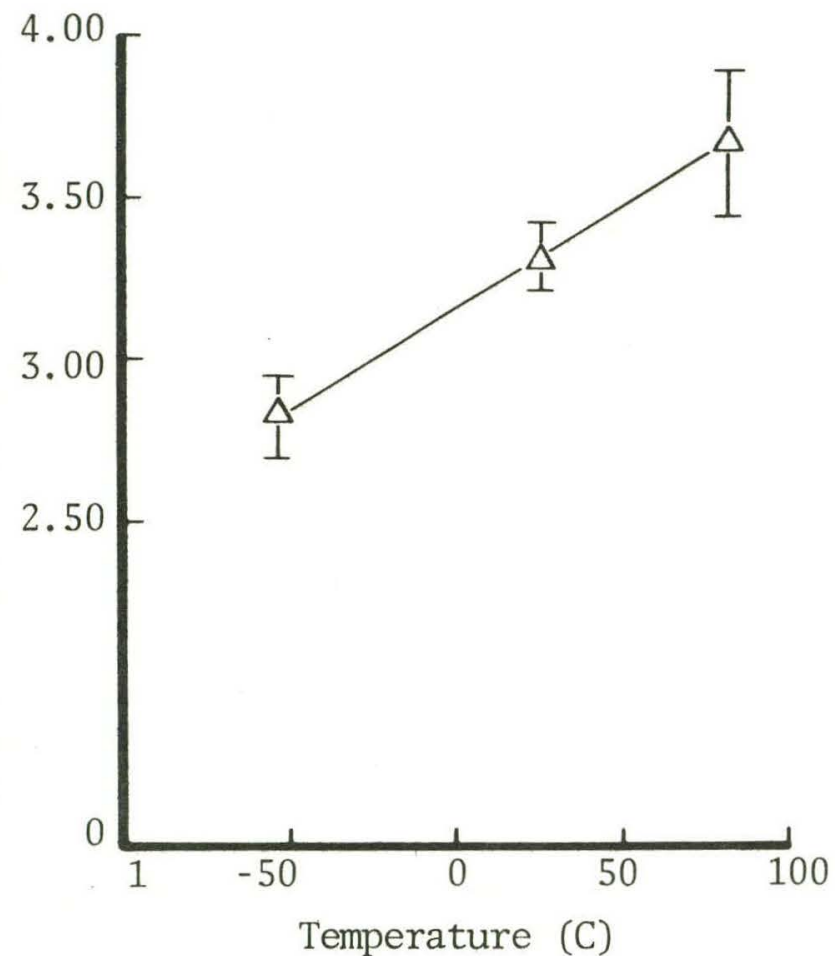

Fig. 8. Depth of cut due to Temperature (Standoff at $1.70 \mathrm{~mm}$ )

THERMAL SHOCK

Performance of the MC 3125 was further evaluated following exposure of twelve units to three 4-hour thermal shock cycles of -54 to $85 \mathrm{C}$. After cycling, three units were tested at $-54 \mathrm{C}$, three at ambient, three at $52 \mathrm{C}(98 \%$

$\mathrm{RH})$ and the last three at 85 C. Fig. 9 illustrates the assembled MC 3125 destruct-test unit. Normally, two detonators are fired simultaneously. In these studies, only one MC 3132 detonator was used for each unit with alternating mounting positions to study propagation through the lap joints from both sides.

71.2 kN Shroud Line

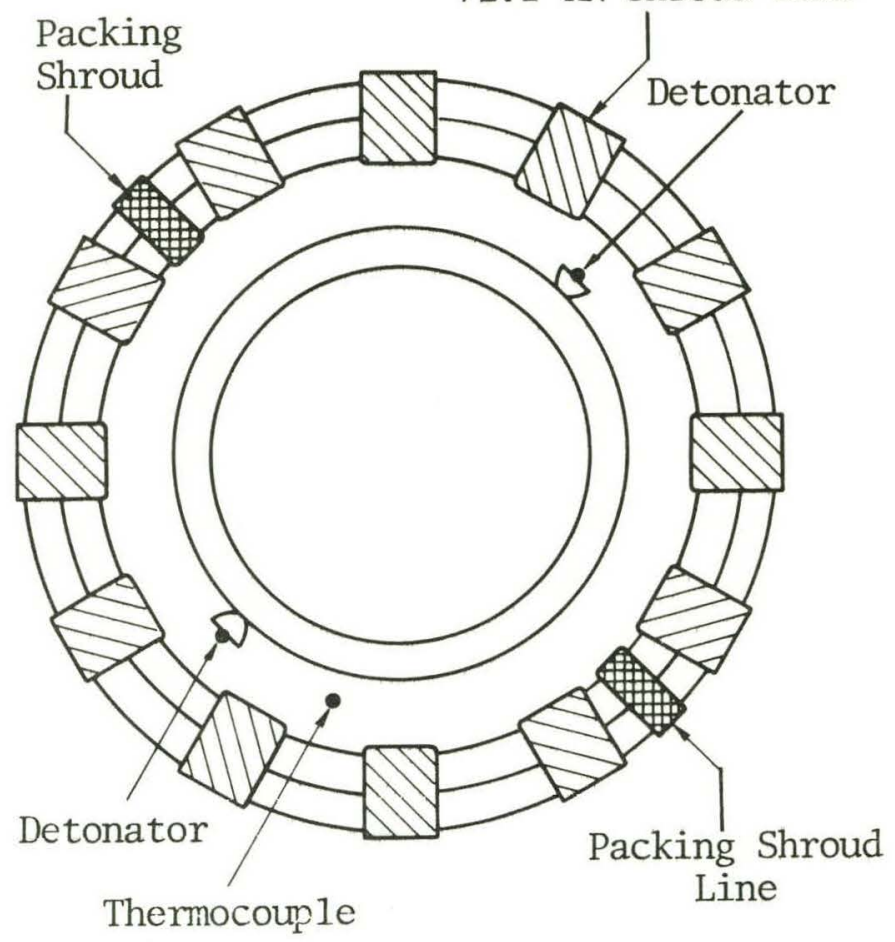

Fig. 9. Thermal Shock Test Assembly

Detonator current and voltage traces were recorded utilizing one dual-trace Tektronix 556 oscilloscope. Fig. 10 shows the circuit for the current supply used to provide the required 5ampere, 7-millisecond step function for the MC 3132 detonator. 


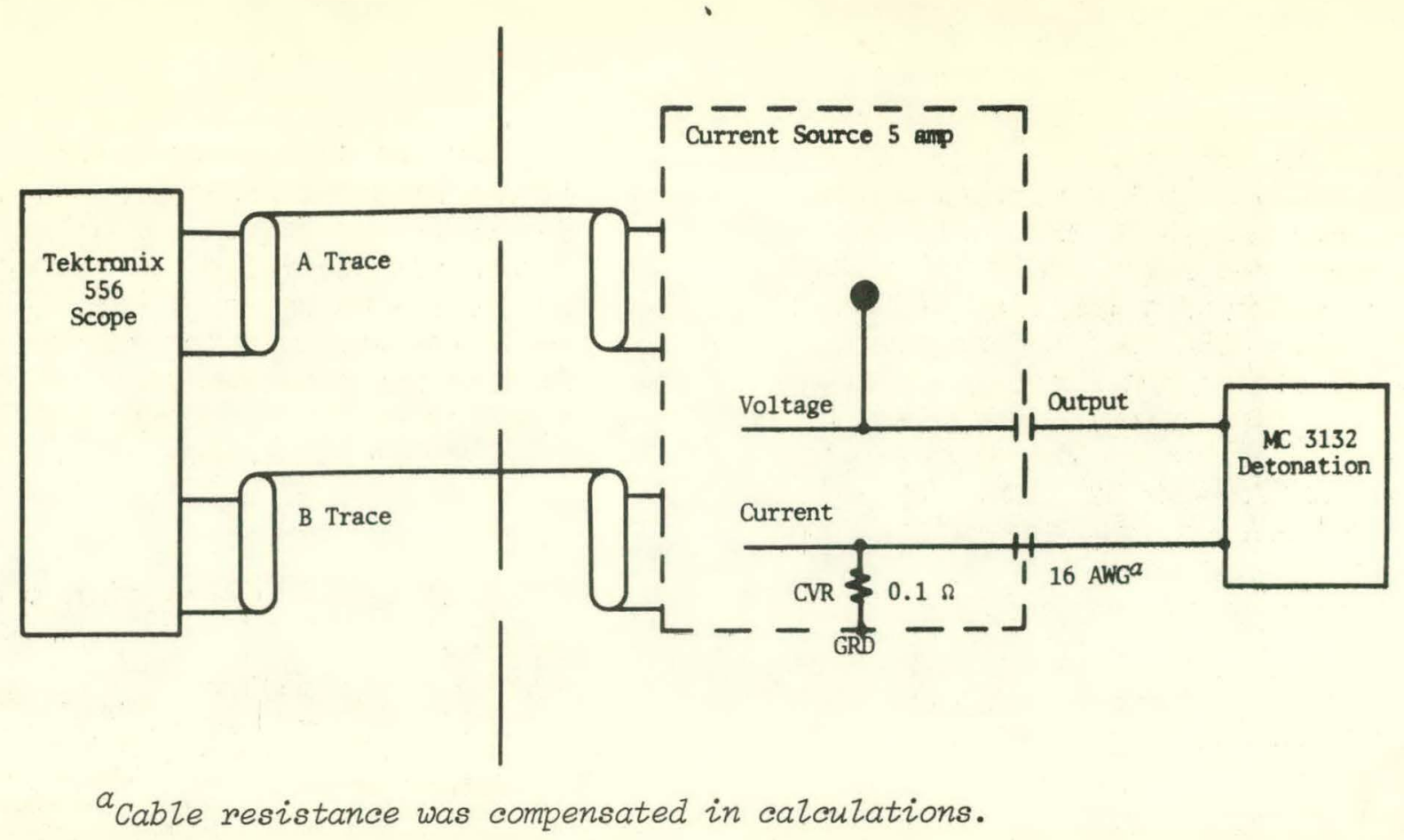

Fig. 10. MC 3132 Detonator Voltage/Current Monitor Schematic

A pin switch coated with $0.013 \mathrm{~mm}$ layer of Parylene was positioned in the ALSC groove 90 degrees from the detonator. This provided a stop-count trigger pulse to a counter. The function time given in Table III is that time from the detonator trigger pulse to the timing switch pulse.
Indications are that the function times were acceptable within an expected time of $1 \mathrm{~ms}$. Figs. 11 and 12 are included to show the oscilloscope traces for current and voltage.

Test results appear to confirm the MC 3125 cutter's ability to function

Table III. Results of Function Time Measurements

\begin{tabular}{|c|c|c|c|c|c|c|c|}
\hline $\begin{array}{l}\text { Shot } \\
\text { No. }\end{array}$ & $\begin{array}{c}\text { Sub-Lot } \\
\text { No. } \\
\end{array}$ & $\begin{array}{c}\text { Final } \\
\text { Temperature } \\
\text { (C/RH) } \\
\end{array}$ & $\begin{array}{c}\text { Function } \\
\text { Time } \\
(\mu \mathrm{s}) \\
\end{array}$ & $\begin{array}{c}\text { Detonation } \\
\text { Current } \\
\text { Peak } \\
\text { (amp) } \\
\end{array}$ & $\begin{array}{l}\text { Bridgewi } \\
\text { Time } A^{\alpha} \\
(\mu \mathrm{S}) \\
\end{array}$ & $\begin{array}{l}\text { Time } \\
\text { Time } B \alpha \\
(\mu \mathrm{s}) \\
\end{array}$ & $\begin{array}{l}\text { Bridgewire }_{b} \\
\text { Resistance } \\
(\Omega) \\
\end{array}$ \\
\hline 1 & 5778 & -54 & 1042.2 & 5.26 & 807.4 & 978.5 & 1.09 \\
\hline 2 & None & -54 & 954.7 & 5.00 & 872.5 & 959.3 & 1.07 \\
\hline 3 & 5779 & -54 & 992.2 & 4.53 & 685.1 & 942.2 & 1.32 \\
\hline 4 & 5778 & 82 & 674.3 & 4.35 & 618.6 & 663.2 & 1.23 \\
\hline 5 & 5777 & 82 & 689.3 & 4.30 & 621.0 & 660.7 & 1.26 \\
\hline 6 & 5766 & 82 & 683.3 & 4.66 & 609.1 & 782.8 & - \\
\hline 7 & 5776 & Ambient & - & 5.33 & 747.8 & 780.6 & - \\
\hline 8 & None & Ambient & 746.0 & 6.09 & 674.5 & 710.5 & - \\
\hline 9 & 5779 & Ambient & 874.4 & 5.30 & 811.6 & 830.6 & - \\
\hline 10 & None & $\mathrm{RH}$ & - & 4.98 & 600.0 & 703.0 & 1.09 \\
\hline 11 & 5776 & $\mathrm{RH}$ & 707.2 & 4.80 & 635.4 & 682.5 & 1.15 \\
\hline 12 & 5777 & $\mathrm{RH}$ & - & 4.04 & 577.3 & 613.2 & 1.37 \\
\hline
\end{tabular}

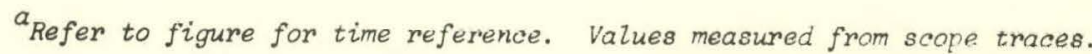

$b_{\text {Values }}$ calculated from voltage and current records. 


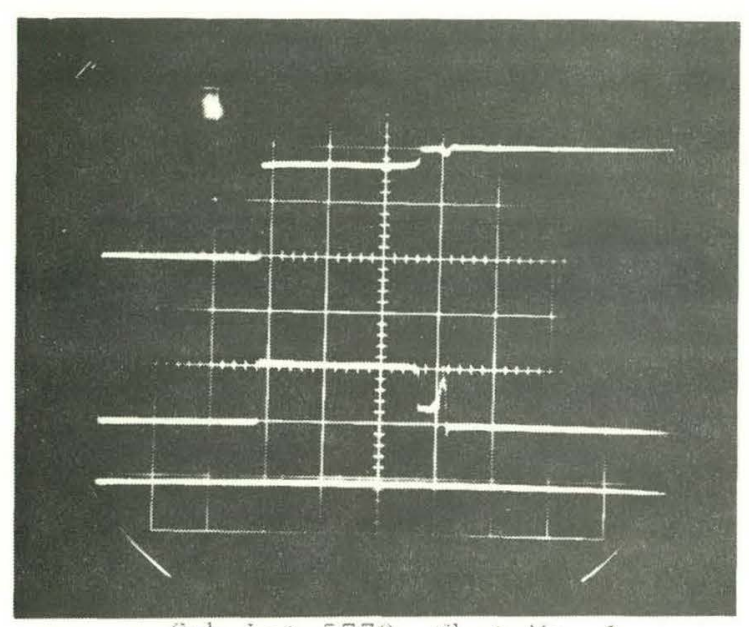

Suh-1.ot 5778, shot No. 1

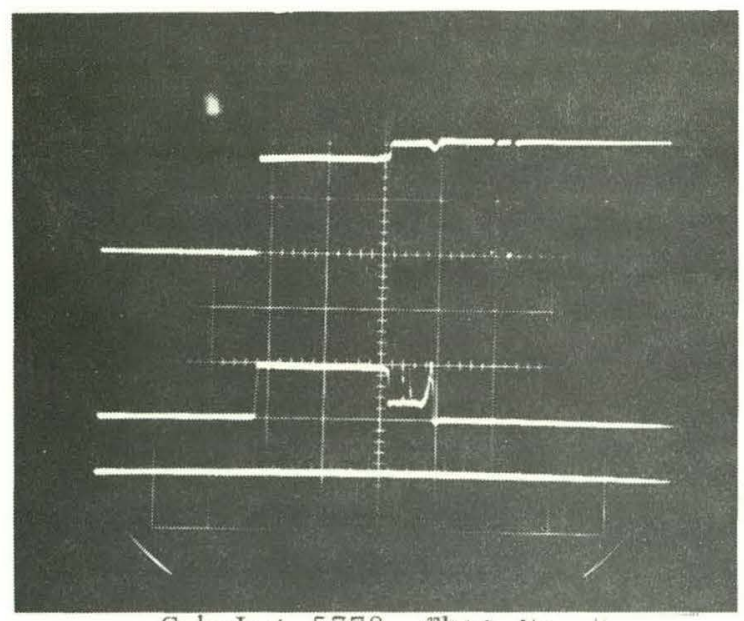

Sul-Lut 5779, Shot No. 3

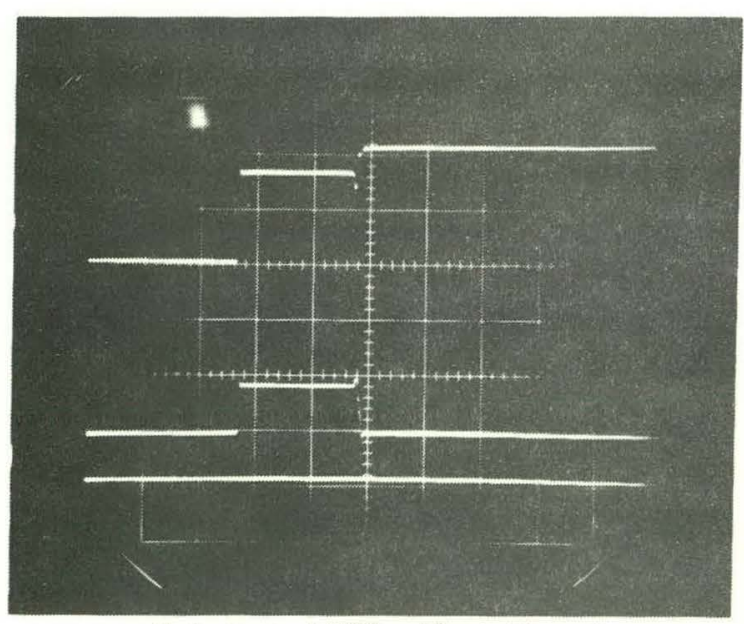

Sub-Lot 5777, Shot No. 5

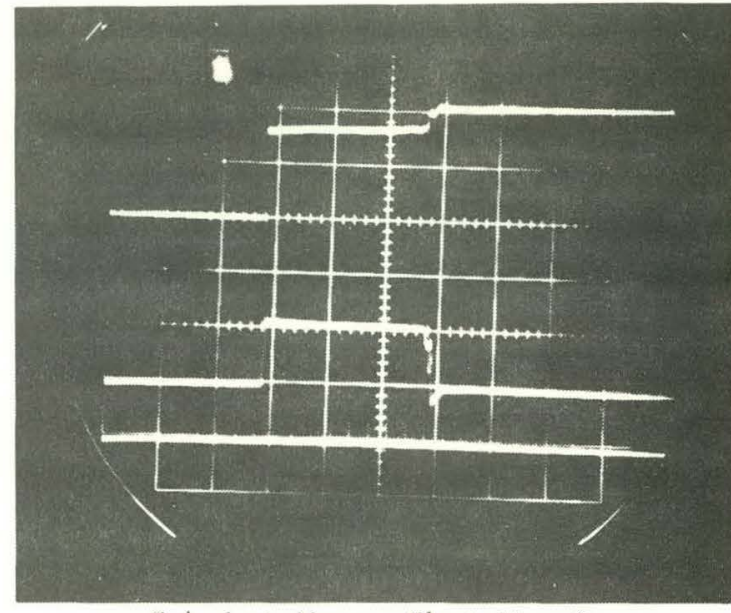

Sub-lot Vone, Shot No. 2

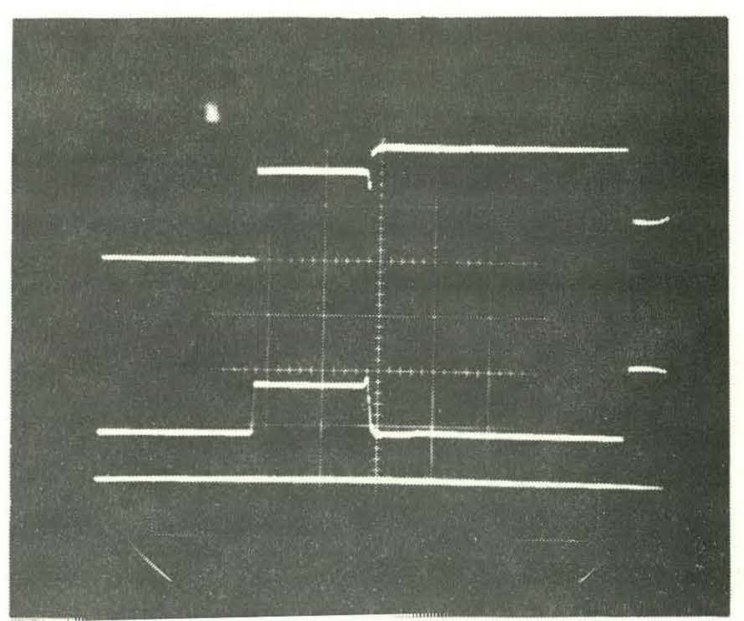

Sub-Lot 5778, Shot No. 4

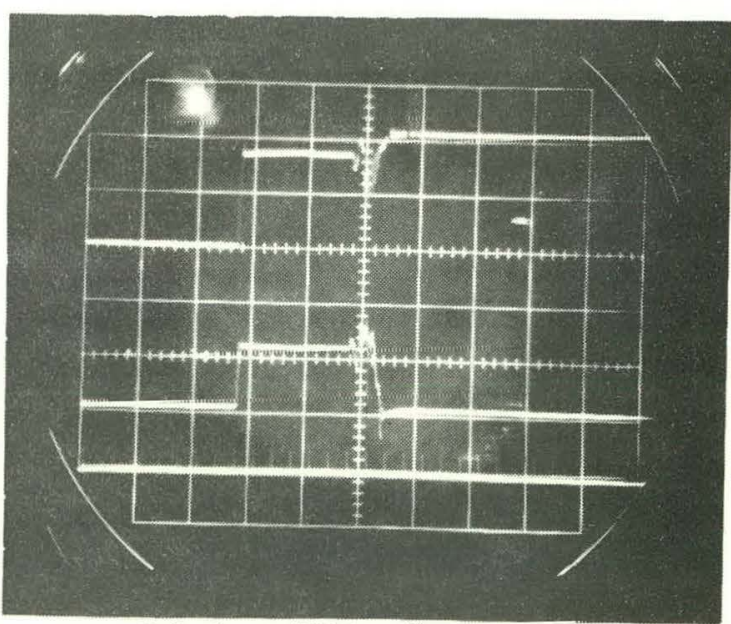

Sub-Lot 5766, Shot No. 6

NOTE: Sweep Speed at $0.3 \mathrm{~ms} / \mathrm{cm}$. Voltage trace at 5 volt/cm and current at $0.5 \mathrm{vozt} / \mathrm{cm}$.

Fig. 11. MC 3132 Detonator Hot Wire Monitor 


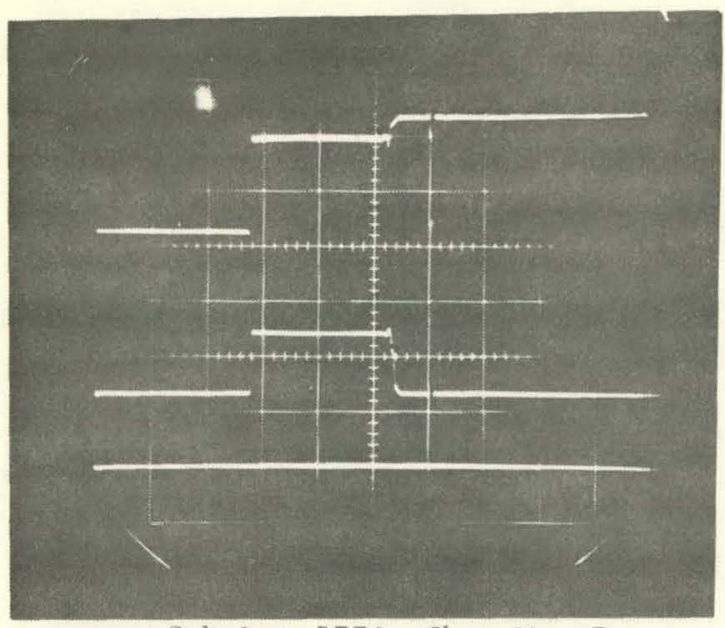

Sub-Lot 5776, Shot No. 7

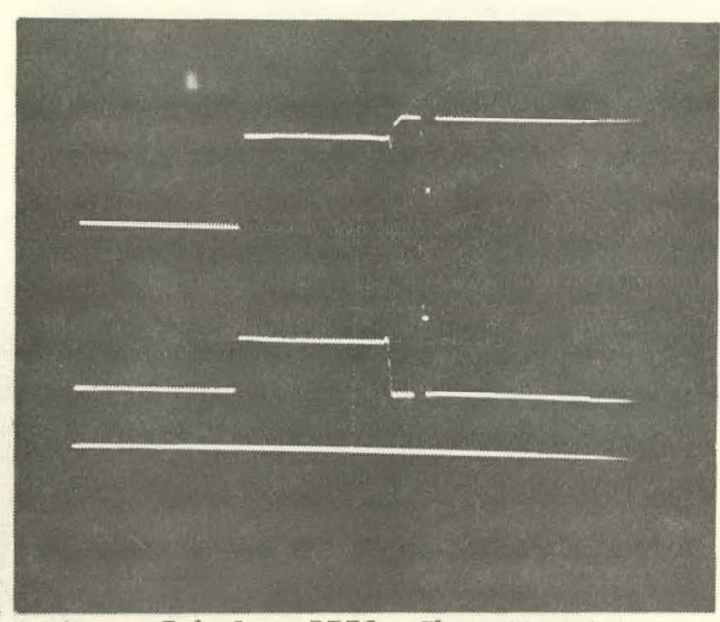

Sub-Lot 5779 , Shot No. 9

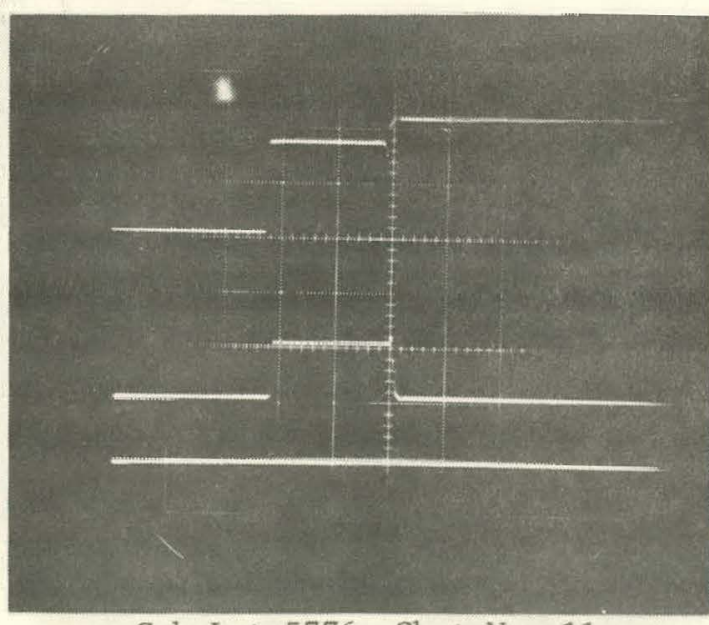

Sub-Lot 5776 , Shot No. 11

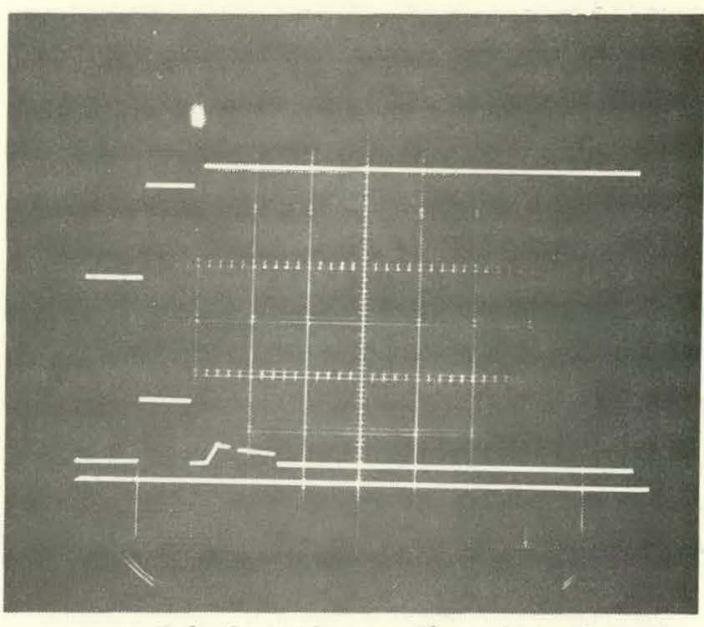

Sub-Lot None, Shot No. 8

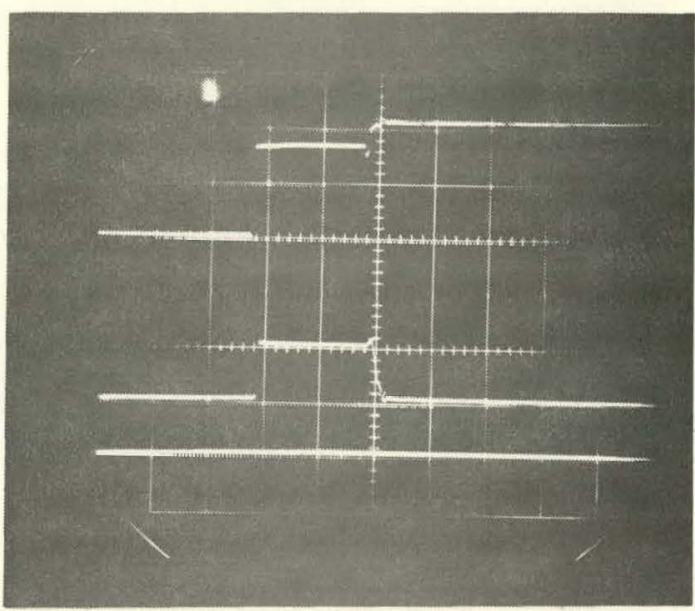

Sub-Lot None, Shot No. 10

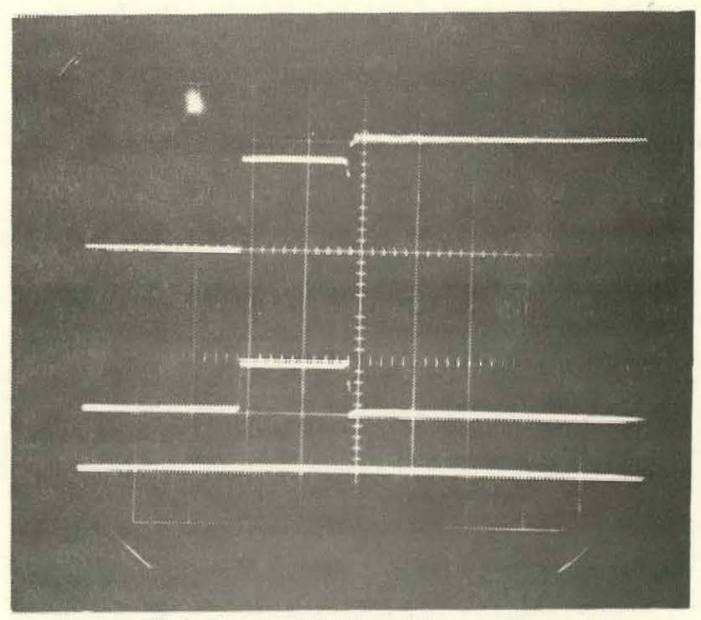

Sub-Lot 5777 , Shot No. 12

NONE: Sweep Speed at $0.3 \mathrm{~ms} / \mathrm{cm}$. Voltage trace at 5 volt/cm and current at 0.5 volt/cm. Shot No. 8 sweep at $0.7 \mathrm{~ms} / \mathrm{cm}$.

Fig. 12. MC 3132 Detonator Hot Wire Monitor 
properly after exposure to thermal shock. However, three units which received a final soak of $52 \mathrm{C}(98 \% \mathrm{RH})$ prior to testing failed to cut $100 \%$ of the shroud lines as shown in Figs. 13, 14 and 15. A close investigation was made to resolve these failures. All test units except Shot No. 12 were equipped with one uncoated $71.2 \mathrm{kN}$ shroud line. In addition, all units were equipped with two $2.4 \mathrm{~mm}$ packing shroud lines. The $71.2 \mathrm{kN}$ shroud line may be expected to fail after absorbing more moisture than one which has a protective coating as indicated in Shots 10 and 11.

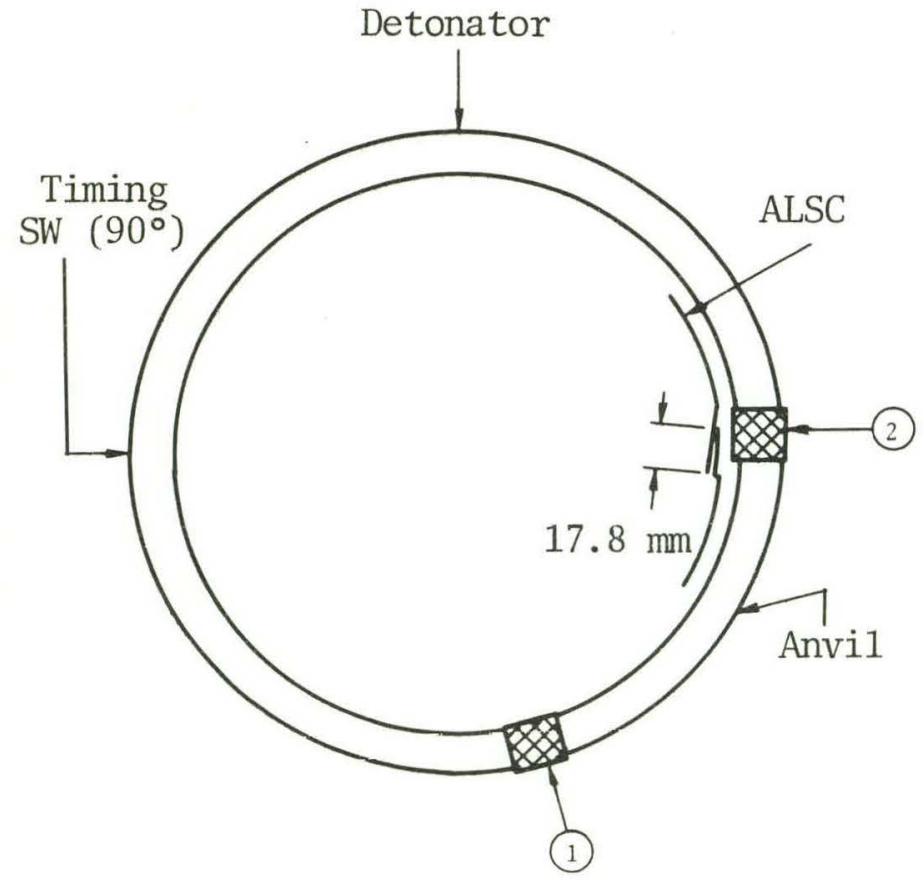

(1) $71.2 \mathrm{kN}$ uncoated shroud line - $60 \%$ cut only. Explanation for failure attributed to excess moisture absorption by uncoated shroud line.

(2) $2.4 \mathrm{~mm}$ thick shroud line failure point - 90\% cut line. Blank spot on anvil behind failure point.

Fig. 13. Shot No. 10 (Final Environment $52 \mathrm{C}, 98 \% \mathrm{RH})$
An attempt was made to randomly position the packing shrouds around the lap joint, since a report $a$ on a lap joint study had disclosed a potential failure zone around the lap joint. Shot No. 10 confirmed this conclusion. It is recommended that the location of the shrouds must avoid this region.

\section{$a_{\text {To be published by Mason \& Hanger }}$ Development Division}

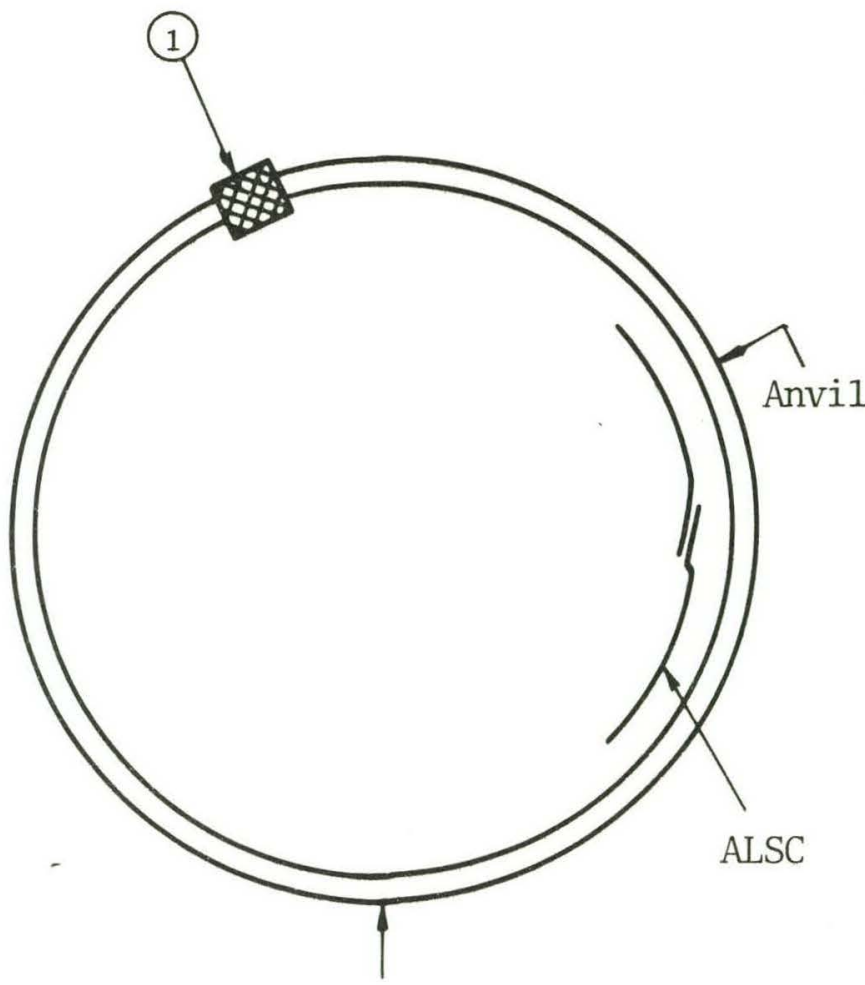

Detonator

(1) $71.2 \mathrm{kN}$ uncoated shroud line - $85 \%$ cut only. Explanation for failure attributed to excess moisture absorption by uncoated shroud line.

Fig. 14. Shot No. 11 (Final Environment $52 \mathrm{C}, 98 \% \mathrm{RH})$ 


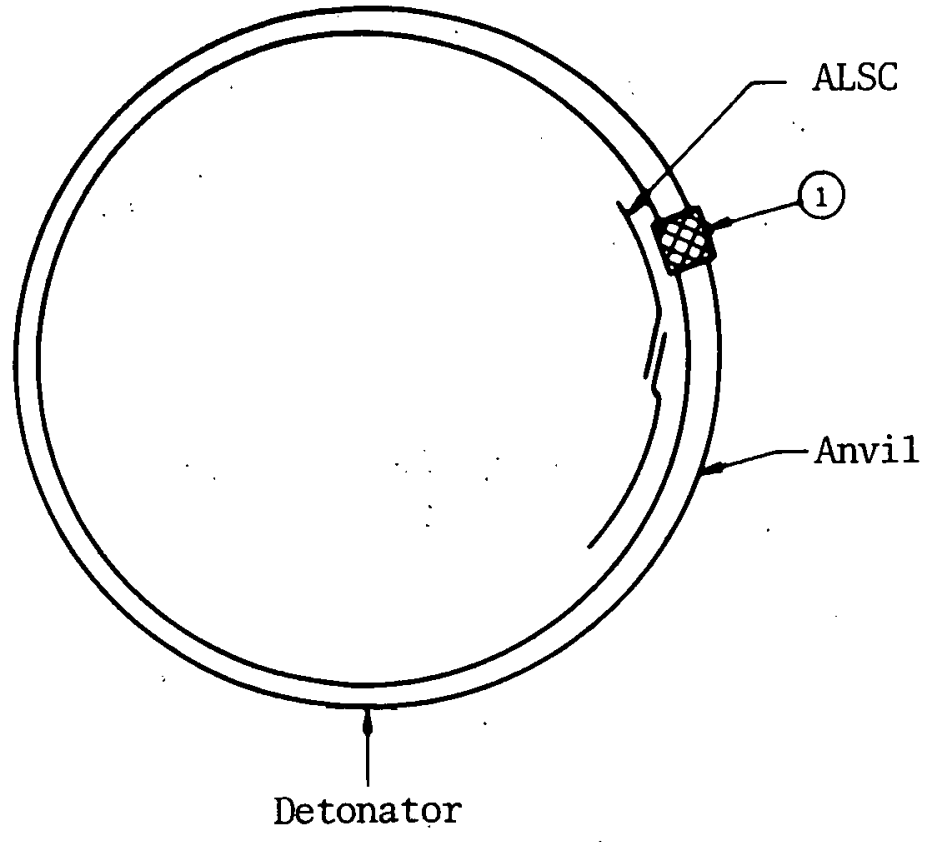

(1) $53.4 \mathrm{kN}$ shroud line failure point - $95 \%$ cut only. No blank spot on anvil detected. No explanation for failure could be determined.

There was no $71.2 \mathrm{kN}$ shroud line tested on this shot.

Fig. 15. Shot No. 12 (Final Environment $52 \mathrm{C}, 98 \% \mathrm{RH})$

\section{SUMMARY}

Results are sumnarized as follows:

1. High and low temperatures have not been shown to adversely affect the cutting of the tested shroud lines. Detonation velocity is not significantly affected.
2. It has been shown that shroud line cutting is not affected after exposure to high humidity, but a failure may be risked if the shroud line is allowed to accumulate excessive water. The limits have not been ex-. amined.

3. The MC 3132 detonators performed as expected following thermal shock conditioning. Test results show the function time to be within acceptable limits.

4. The lot qualification test technique did show inconsistencies in the data; however, the problems are understood and future work will be expended to correct for them. This technique is being proposed for manufacturing lot qualification. Two major results can be presently obtained which include depth of rupture and cutting depth.

5. It was shown in the lot qualification tests that cutting depth and depth of rupture increase with temperature.

6. It was necessary to investigate the effects bending ALSC might have on the detonation velocity since cutting ability is a function of velocity. Test results have shown that detonation velocity is not significantly affected by bending the AIsSC to as small as $50 \mathrm{~mm}$ in radius. 